\title{
An Exploration of Progression Rates of Widening Participation Students on to an Integrated Master of Engineering
}

\author{
Tania Humphries-Smith ${ }^{1} \&$ Clive Hunt ${ }^{1}$ \\ ${ }^{1}$ Bournemouth University, Department of Design \& Engineering, Poole, UK \\ Correspondence: Tania Humphries-Smith, Bournemouth University, Department of Design \& Engineering, Poole, \\ Dorset, BH12 5BB, UK. Tel: 44-1202-961-402.
}

Received: June 19, 2017

Accepted: July 10, 2017

Online Published: July 23, 2017

doi:10.5430/ijhe.v6n4p69

URL: https://doi.org/10.5430/ijhe.v6n4p69

\begin{abstract}
This paper reports on an investigation into the potential to widen participation to Higher Education provided by a flexible learning MEng Engineering. The MEng is part of an integrated programme that provides progression routes from a traditional day release Apprenticeship, through HNC, FdEng at a Further Education College to a flexible learning BEng/MEng at a Higher Education Institution. The programme was originally developed to answer a demand from local industry to upskill the engineering workforce, however, the nature of the provision means that it meets much of the best practice for widening participation. The investigation concludes that while the programme provides an opportunity for mature learners to undertake higher education, it largely provides an alternative pathway through vocational education to higher education qualifications for a white male middle class cohort. It also highlights that entry to apprenticeships that lead to progression opportunities is controlled not by educational institutions but by industry.
\end{abstract}

Keywords: Widening participation, MEng Engineering, Engineering education, Flexible learning, Apprenticeships

\section{Introduction}

\subsection{The Problem}

This paper reports on an investigation into the impact on widening participation (WP) of a flexible learning Master of Engineering (MEng) (Hons) Engineering course at Wessex University (WU), located in the south of England. The MEng course is part of an integrated pathway that commences with an Apprenticeship (level 3) (Note 1) and can lead to studying for a Higher National Certificate (HNC) at level 4, then onto a Foundation Degree Engineering (FdEng) at level 5 which are all studied at a local Further Education (FE) College. Further progression is then possible to study for a Bachelor of Engineering (BEng) at level 6 and finally a Master of Engineering (MEng) at level 7, both of which are delivered by WU in flexible learning mode. To complete the HNC takes two academic years, the FdEng one calendar year and the BEng and MEng levels two academic years each, resulting in 7 years of Higher Education (HE) study to gain the MEng award. The course was originally developed as part of a Higher Education Science, Technology, Engineering and Mathematics (HESTEM) National Programme project and provides an opportunity for engineers to take higher education qualifications while remaining in full time employment. The programme is accredited for Incorporated and Chartered Engineering academic requirements through the Institution of Engineering Designers (IED). The first 4 cohorts have all progressed from part time, day release Foundation degree Science (FdSc)'s or Engineering (FdEng)'s at an FE College to take units at level 6 (Bachelors) and level 7 (Masters).

\subsection{Importance of the Problem}

The drive to widen participation in HE is an international phenomena with contested but broadly similar definitions

WP is largely concerned with redressing the under-representation of certain social groups in higher education

(Burke, 2016). There are also numerous issues around measuring and recording the related metrics (Bowes et al, 2013, Gale and Parker, 2013, Gorard, 2008, Osborne, 2003). However, this study is only concerned with the UK context and will take the definitions of WP and associated metrics from current government policy. Moreover, this study focuses on WP in the specific context of apprenticeships. The research aims to discover whether an unintended consequence of the development and delivery of this programme over the 4 academic cycles now operated has led to a greater number of students from WP backgrounds participating in Higher Education (HE). This is particularly 
important in the light of the Government's current focus on increasing the number of apprentices and ongoing focus on increasing participation from WP backgrounds, especially given the ongoing shortages of young people entering the engineering professions.

The following abbreviations are used throughout tables in this paper - Higher National Certificate year 1 (HNC1); Higher National Certificate year 2 (HNC2); Foundation Degree Engineering (FdEng); Bachelor of Engineering year 1 (BEng1); Bachelor of Engineering year 2 (BEng2) and Master of Engineering (MEng).

Table 1. Student numbers by cohort

\begin{tabular}{lcccccc}
\hline & $\begin{array}{c}\text { HNC1 } \\
(\mathrm{FE})\end{array}$ & $\begin{array}{c}\text { HNC2 } \\
(\mathrm{FE})\end{array}$ & $\begin{array}{c}\text { FdEng } \\
(\mathrm{FE})\end{array}$ & $\begin{array}{c}\text { BEng1 } \\
(\mathrm{WU})\end{array}$ & $\begin{array}{c}\text { BEng2 } \\
(\mathrm{WU})\end{array}$ & $\begin{array}{c}\text { MEng } \\
(\mathrm{WU})\end{array}$ \\
\hline Academic year 2012/13 & 37 & 20 & 9 & 16 & & \\
Academic year 2013/14 & 23 & 35 & 17 & 10 & 16 & 3 \\
Academic year 2014/15 & 50 & 24 & 28 & 17 & 10 & 1 \\
Academic year 2015/16 & 54 & 47 & 30 & 20 & 16 & 0 \\
\hline
\end{tabular}

Encouragingly the student cohort has grown as indicated in Table 1 below over the last four academic years (AY) meaning more qualified engineers are available for the local economy. It should be noted that while the majority of students progress sequentially through the levels it is possible for a student from outside the integrated programme to enter at any level providing they hold appropriate entry qualification.

\subsection{Policy Literature}

The UK Government has long held a policy of increasing participation in Higher Education (HE) from people with backgrounds who do not traditionally enter HE. The developing policy is set out in the White Paper, Meeting the Challenge (Department for Education and Schools [DES], 1987) and the 1991 White Paper, Higher Education: a new framework (DES, 1991) culminating in the Dearing and Fryer reports of 1997 (Dearing, 1997, Fryer, 1997). Although the effect of all these reports was to increase and widen access to HE it was not until Dearing that the emphasis was put upon increasing numbers of people entering HE from the lower socio-economic groups. The White paper Learning to Succeed: a New Framework for Post-16 Learning (Department for Education and Employment [DfEE], 1999) was the final paper in the $20^{\text {th }}$ century in this long line. This idea has been termed widening participation (WP). It should be noted that since 1999 the UK government has only had responsibility for HE in England.

As long ago as 1993 the percentage of those entering HE from socio-economic groups skilled manual occupations (IIIM), partly skilled occupations (IV) and unskilled occupations (V), was noted as remaining virtually static in the National Committee on Education report, 1993. This report quotes the UCCA/PCAS statistics for 1992 for participation in $\mathrm{HE}$ by social class, as being $58 \%$ for classes I (professional occupations) \& II (managerial \& technical occupations), and a further $23 \%$ from classes III A (supervisory \& junior managerial) \&B (skilled manual).

The National Audit Office report - Widening Participation in Higher Education in England (2002) identifies the four groups with historically low participation in higher education as women, social classes IIIM, IV \& V, ethnic minorities and people declaring disabilities. Of these four groups the only one not to see increased participation in higher education between 1994/5 and 1999/2000 was people from social classes IIIM, IV \& V.

Entering the $21^{\text {st }}$ century the 2003 White Paper -The Future of Higher Education (Department for Education and Skills [DfES], 2003) places a continuing importance on widening participation but also makes a clear distinction between expanding higher education and achieving Fair Access, that is, widening participation to include all sectors of society. In a subsequent briefing by Charles Clark, Education Secretary it was clearly stated that:

...the government's previous top-priority target of getting 50 per cent of 18-30 year olds into university was less important to him than ensuring 'a much better class basis' in the 43 per cent currently attending. (THES, 10/01/03:18)

It also introduces the Access Regulator or Office for Fair Access (OFFA) as it subsequently became known, to ensure that Universities are inclusive in their admissions policies if they want to charge top-up fees. Metrics have been developed to measure WP, these are subject to change over time but are currently: type of school; free-school meals; socio-economic classification (Office of National Statistics NS-SEC) (note this changed in 2002/3 and is due to change again in 2017); low-participation neighbourhoods (POLAR3 from 20011/12 and POLAR2 from 2006/7); 
disabled people; care leavers; mature students; part-time learners as published by OFFA.

An Interim Report on the development of a National Strategy for WP was published in 2013 (Higher Education Funding Council for England [HEFCE] and OFFAa, 2013:16) and concluded, amongst other points, in terms of preparation for access to HE that 'Progression pathways for learners with non-traditional or vocational qualifications need to be clearly articulated'.

The National Strategy for Access and Student Success (HEFCE and OFFAb 2014:10) highlights the "development of flexible study options that meet the needs of students and employers.". It also reports, based on POLAR3 classification, that

...the rate of young entry to HE from the most disadvantaged quintile has increased from 13 per cent to 20 per cent (seven percentage points or a proportional increase of 52 per cent) between the 98:99 cohort and the 11:12 cohort (HEFCE and OFFAb 2014: 18)

However, it must be noted that during the same period the participation rates of the highest quintile (Q5 - areas of highest participation), rose from $51 \%$ to $60 \%$ meaning that Q5 were still 3 times more likely to participate than Q1 (areas of lowest participation). Additionally, participation rates for quintile 1 men only rose from $12 \%-17 \%$ during the period while it rose from 15\%-23\% for women and participation rates on part-time courses have decreased, albeit not for students studying at intensities above $25 \%$ and thus eligible for loans. The strategy document also highlights a paucity of information on how universities work with employers in developing part time provision and clearly sets outs

HE-employer engagement as a growing national priority and found signs that recent developments in funding for workforce development initiatives have helped to increase participation in HE - for example the Higher Apprenticeship Fund and co-funded provision. But there are issues around the extent to which disadvantaged groups are benefiting from these programmes. For example, research cited in the literature review suggests that those from lower socio-economic groups are less likely to be supported to study by their employer and that apprentices from widening participation target areas are less likely to go into full-time university provision than those from more advantaged areas. (HEFCE and OFFAb 2014: 42).

The document also notes that

... supplementary admission/progression routes has the greatest impact on access and retention, particularly when accompanied by pedagogical reforms and activities that build up socio-cultural capital and familiarity with HE. (HEFCE and OFFAb 2014: 40).

and identifies that

The process of applying to and entering HE can be daunting for anyone, but especially so for learners from more disadvantaged backgrounds - particularly if they are the first in their family to go to university or college. (HEFCE and OFFAb 2014: 41)

The latest guidance to OFFA from the UK Government was issued in Feb 2016, replacing the previous guidance of Feb 2011. In this guidance and the Green Paper, Fulfilling our Potential: Teaching Excellence, Social Mobility and Student Choice, (Department for Business Innovation and Skills [BIS], 2015) an emphasis is put upon the need to improve participation amongst young white males from lower socio-economic groups, whose participation is particularly poor (OFFA, 2016:1)

In the context of this paper it is also important to note the introduction in April 2016 of the Institute of Apprenticeships and Technical Education (Note 2) and the associated introduction of the Apprenticeship Levy from April 2017 (Her Majesty's Revenue and Customs [HMRC], 2016). Essentially the policy requires all companies with a payroll over a minimum limit pay a proportional amount into a fund they can then draw down upon to pay for apprentices and their training. Part of the draw down funding includes initiatives to incentivise the employment of apprentices from various backgrounds including those considered to be from deprived areas (Department for Education [DfE], 2017). Associated with this is the expansion of apprenticeships to degree level, the so called Degree Apprenticeships (BIS, 2015) allowing funded HE to be accessed by companies for their apprentices. These developments also need to be seen in the light of UK Government statistics that show increasing numbers of apprenticeships being taken (Mirza-Davies, 2016).

\subsection{Critical Literature}

Burke (2013) offers a critique of the policy discourse on WP holding the view that the attention now being placed upon men's lack of participation is too simplistic and potentially dangerous. This echoes the work of Connell (2000) 
who draws attention to inequalities in class and race that are ongoing. Burke suggests that there is a complex, embedded, history related to gender, class and ethnicity associated with access and participation in education.

Burke (2013) also discusses the progression of apprentices to HE, citing, Milburn, 2009 stating that only 0.2 per cent of apprenticeship learners progress onto further or higher education, and few directly into the professions. The longitudinal studies of Smith, Joslin \& Jameson (2015), Joslin \& Smith (2013) and Joslin \& Smith (2014) that tracked the progression of 6 cohorts of apprentices over a period of 6 years provide data that would seem to contradict this

19.3\% of the 2006-07 tracked apprentice cohort progressed to higher education when tracked for a total of seven years. This rate of progression is an increase on the seven year rate of 18.8\% found for the 2005-06 cohort in the previous study in this series (Smith, Joslin \& Jameson, 2015:8)

however, it must be noted that this study tracked advanced level apprenticeships ie a level 3 qualification equivalent to 2 A levels, thus this does not include all apprenticeships the majority of which are at level 2 (Higton, Emmett, \& Halliday 2013:8) across all sectors, with 58\% being level 2 in Engineering \& Manufacturing Technology. Joslin \& Smith (2014:36) state that $37 \%$ of advanced engineering apprentices progressed to some form of HE in 2005/6 but this had dropped to $22 \%$ by 2009/10. However, Smith, Joslin \& Jameson (2015:36) state an increased figure of $31 \%$ for 2009/10 recognising that engineering apprentices take longer to progress than other frameworks.

Colahan \& Johnson (2014) report on apprenticeships from the employer perspective across all sectors that offer apprenticeships. Colahan \& Johnson report that

Of those who had Level 3 apprentices complete their training in the reference period, over half (54\%) said they offered some form of progression to higher level qualifications, and one in four (24\%) had apprentices who had gone on to study these. (2014:10)

Archer et al (2001) investigated the issues around white male working class participation in HE, citing studies from as early as 1970s to late 1990s when the issues became a focus of government policy (National Committee of Inquiry into Higher Education [NCIHE], 1997; Department for Education and Employment [DfEE], 1998). Archer et al highlighted among other issue related to finance, risk etc that

On the surface, many young men in these groups seemed to approach education, either at school or college, or their future working lives, in a disorganised and haphazard manner. For example, many had arrived at FE college through routes that appeared to be chaotic or by chance. Very few men reported any kind of 'plan'...

(Archer et al, 2001:443)

The latest guidance from the UK Government to OFFA discussed earlier is still seeking to address this issue. However, Smith et al (2015) report that $22 \%$ of advanced level apprentices were classified as coming from the most educationally disadvantaged backgrounds, namely, POLAR2 quintile 1 (note POLAR2 has now been replaced by POLAR3) which is discussed later. Joslin \& Smith (2014:7) suggest that apprentices progressing to part-time HE are an under-researched group, requiring further analysis related to age, gender and framework of study in order to improve progression rate.

\subsection{Research Question}

So the development of the flexible learning MEng, described in the introduction, provides an integrated and structured progression route to HE for engineering apprentices which sits outside the 'normal' progression routes as is tailored pedagogically to the student body, provides an opportunity to build up familiarity with HE while in an FE environment and was developed in collaboration with employers. Thus it would appear that this pathway offers many of the features suggested by the National Strategy document (2014). The integrated pathway provides a good opportunity for the further research suggested by Joslin \& Smith (2014) to investigate progression and specifically to determine whether it fulfils the widening participation agenda described in government literature.

Thus, the question to be answered is whether the integrated MEng programme actually does increase the participation in $\mathrm{HE}$ of engineering apprentices from widening participation target areas and if so why this might be so?

\section{Method}

The research took a qualitative methodological approach, however, an amount of supporting quantitative data was collected. 


\subsection{Data Collection Methods}

In order to get accurate data on the WP metrics a questionnaire was conducted in which quantitative data was requested on: gender, ethnicity, age, Senior School attended, GCSEs obtained, occupation of parent/guardian (based on coding from the Office for National Statistics (NS-SEC rebased on SOC2010)), whether respondent had free school meals, post code of home address whilst at school and whether their parent/guardian holds a degree. Additional qualitative data was collected on the same questionnaire via two open questions:

How did you get to this point in your career - please describe your journey from school to today.

Who influenced you to choose this career choice?

A second questionnaire was undertaken that sought qualitative data in the form of answers to the questions around why respondents wanted to progress, what would stop them progressing and whether an integrated route was important to them.

\subsection{Participant Characteristics \& Sampling}

Participants were requested from all student cohorts from Higher National Certificate year 1 (HNC1); Higher National Certificate year 2 (HNC2); Foundation Degree Engineering (FdEng); Batchelor Engineering year 1 (BEng1); Bachelor Engineering year 2 (BEng2) and Master Engineering (MEng) at both WU and the partner FE College. This amounts to a total of 168 possible respondents.

The second questionnaire was used with the same cohorts as the first questionnaire plus the Subsidiary Diploma (SD) cohort comprising 23 students. The Subsidiary Diploma cohort was included in order to gain some insight into the level of awareness of progression opportunities and whether there was strategic planning of their career occurring.

\subsection{Research Design}

Questionnaires were chosen as the preferred data collection method due to the nature of the respondents and the access limitations. It was only possible to gain access to the respondents during the time their 'day release' attendance at the FE College, with time being very limited. Additionally, it was felt that questionnaires would be perceived as less intimidating than either focus groups or interviews. Additionally, the questionnaire process was enacted by one of the researchers and not one of the respondents college lecturers.

The questionnaire was conducted during taught classes FE College or WU as appropriate to level of study and was anonymous, although contact details were requested on a voluntary basis. Ethical compliance permission was obtained prior to the commencement of the study, and ensured by the participation being voluntary and individuals being free to withdraw at any time. Anonymity has been maintained for both individuals and institution

\section{Results}

\subsection{Quantitative Data Analysis}

Table 2. Number of respondents on each level/course and gender

\begin{tabular}{|c|c|c|c|c|c|c|c|}
\hline & $\mathrm{HNC1}$ & HNC2 & FdEng & BEng1 & BEng2 & MEng & Total \\
\hline $\begin{array}{l}\text { Number of } \\
\text { respondents }\end{array}$ & 46 & 26 & 22 & 11 & 12 & 1 & 118 \\
\hline $\begin{array}{l}\text { Number of } \\
\text { Males }\end{array}$ & 41 & 26 & 21 & 10 & 12 & 1 & 111 \\
\hline
\end{tabular}

118 responses were received from a potential total of 168 for the first questionnaire and are broken down by cohort of study in Table 2. Table 2 also shows that 111, or $94 \%$ are of male gender, this is in line with the sector for Engineering and Manufacturing Technology stated as 94\% (Colahan \& Johnson, 2013, p8), with 92\% being of white British/English ethnicity.

Table 3. Proportion of students by age

\begin{tabular}{lcccc}
\hline Age in years & $18-21$ & $22-25$ & $26-30$ & $30+$ \\
\hline$\%$ of respondents & $37 \%$ & $39 \%$ & $13 \%$ & $11 \%$
\end{tabular}

In terms of age Table 3 breaks this into 5 year gaps for all respondents and indicates that the majority of students are aged under 25 , as expected, however, $24 \%$ are aged over 25 with $11 \%$ aged over 30 . The number of students aged over 25 is much higher than commonly seen on WU courses even taking into account that the part time nature of the courses results in longer study periods. 
Table 4. Occupations of parent/guardian

\begin{tabular}{lcccccccc}
\hline $\begin{array}{l}\text { Parental } \\
\text { occupation }\end{array}$ & HNC1 & HNC 2 & FdEng & BEng1 & BEng 2 & MEng & Total & $\%$ \\
\hline class 1 & 8 & 9 & 7 & 1 & 4 & & 29 & $25 \%$ \\
class 2 & 17 & 11 & 5 & 6 & 4 & & 43 & $36 \%$ \\
class 3 & 5 & 1 & 6 & 1 & 1 & & 14 & $12 \%$ \\
class 4 & 2 & 1 & & 1 & & & 4 & $3 \%$ \\
class 5 & 6 & 2 & 1 & 1 & 3 & 1 & 14 & $12 \%$ \\
class 6 & & 1 & 3 & & & & 4 & $3 \%$ \\
class 7 & 2 & 1 & & & & & 3 & $3 \%$ \\
class 8 & 3 & & & & & & 3 & $3 \%$ \\
\hline
\end{tabular}

Respondents indicated that $34 \%$ of their parents/guardians had degrees with $61 \%$ holding class 1 or 2 occupations, see Table 4. Class definitions are based on coding from the Office for National Statistics (NS-SEC rebased on SOC2010)) with Class 1 and 2 being defined as higher and lower managerial, administrative and professional occupations respectively while Class 3-7 range from intermediate occupations to routine occupations with Class 8 being long term unemployed. WU's Fair Access Agreement 2016/17 indicates in Appendix 2 that as an institution it has between $25.6 \%$ (2014/15) and 30.4\% (2013/14) of students with parents having class 4-7 occupations which broadly correlates with $25 \%$ of the study cohort.

Table 5. Respondents POLAR3 quintiles whilst at school

\begin{tabular}{cccccccc}
\hline $\begin{array}{c}\text { POLAR 3 } \\
\text { Quintile }\end{array}$ & HNC1 & HNC2 & FdEng & BEng1 & BEng2 & Total & $\%$ \\
\hline 1 & 7 & 2 & 1 & & & 10 & $8.6 \%$ \\
2 & 7 & 6 & 5 & 1 & 3 & 22 & $19.5 \%$ \\
3 & 13 & 9 & 5 & 4 & 6 & 37 & $32.7 \%$ \\
4 & 11 & 7 & 6 & 3 & 2 & 29 & $25.7 \%$ \\
5 & 6 & 2 & 4 & 2 & 1 & 15 & $13.3 \%$ \\
\hline
\end{tabular}

113 of the 118 respondents provided postcode of domicile while at school, this was analysed against POLAR3 quintiles as shown in Table 5 using HEFCE postcode checker. POLAR3 quintiles (HEFCE 2015) indicate the likelihood of a young person from a specific postcode participating in higher education with quintile 5 being most likely and quintile 1 least likely. Actual percentages for each quintile vary considerably, however, the range for areas significant for this study are quintile $1-10.4-19.1 \%$ and for quintile $5-47.5 \%-71.4 \%$ (HEFCE 2017). Higher Education Statistics Agency (HESA) in UKPEI Definitions states 'Those students whose postcode falls within wards with the lowest participation (quintile 1) are denoted as being from a low participation neighbourhood.' WU's Fair Access Agreement 2016/17 indicates in Appendix 2 that as an institution it has around 10\% of Low Participation Neighbourhoods (LPN) students ie slightly higher than the study cohort - see Table 5.

\subsection{Qualitative Data}

Qualitative data was collected on progression routes which when grouped, suggests 50\% progressed from A or AS level study, with 30\% progressing direct from GCSE level study. A further 13\% progressed from other work and 5\% from military service.

The study also considered the school attended by the respondents, the results of this were that 26 schools within a radius of 40 miles of the location of the FE College/WU were named with two sharing $22 \%$ of the respondents. Only 5 of the schools named were considered as WP schools by a sample of contextual admissions data.

Qualitative information was also sought on where respondents got careers advice or influence from this indicated that a majority $(53 \%)$ received their careers advice/influence from parents/family, with $56 \%$ of those declaring parental occupations in class $1 \& 2$ received their careers advice/influence from parents/family.

The second questionnaire indicated that an increasing number of students (rising from $43 \%$ to $68 \%$ ) were aware of the full integrated programme on starting their Apprenticeship. Significant numbers (40-60\%) are intending to follow 
their study through to BEng level, with a severe decline in numbers, to around $10 \%$, intending to continue to MEng level.

Answers to the qualitative questions, in the second questionnaire, clearly indicate that the main reason for wanting to progress was career and salary progression, with professional recognition rarely mentioned. It was also clear that the existence of a well mapped out integrated programme encourages students to continue their education, as one student stated 'I didn't plan to get this far'. It was noted in the qualitative data that 7 years for the complete programme was seen as daunting when setting out on an Apprenticeship and that the possibility to take a break in studies was an important option. The reasons given for selecting their career path in the qualitative data collected suggest a level of disaffection with academic work, as is evidenced by: 'dropped out of A levels'; 'didn't want to go to Uni'; 'I knew I didn't want to do A levels/Uni'; 'didn't achieve A level grades representative of my ability so didn't think it was worth going to Uni' ; 'didn't want to go to Uni and didn't like school'; 'realised university was not the route I wanted to take' and importantly 'considered university courses in Physics/Engineering but received a good apprenticeship offer to a higher apprenticeship'.

Interestingly, however, the point was made that some companies do not want their employees to progress beyond certain points and this may lead to a refusal to sponsor students on the full programme.

The qualitative data revealed that changes made after review of the first delivery lead to a good transition between study in an FE college and at WU - the comment was made that 'What we did last year transitioned nicely.' It was also noted that the use of students' who had previously made the progression to brief the upcoming cohort on expectations, in particular of academic support, assessments types and the perceived 'vagueness' of higher level study made the transition easier. Generally the transition between the FE College and WU was not perceived as being intimidating and reflections included attendance at University being a 'breath of fresh air' with a more professional and mature feel. This suggests that the integrated programme does 'build up socio-cultural capital and familiarity with HE' in line with The National Strategy document (2014, p40).

Thus, the qualitative and quantitative data provides a comprehensive picture with the quantitative data providing factual information about the backgrounds of the students progressing to HE levels of the integrated pathway while the qualitative data, when analysed, provides some of the complex picture that describes how progression decisions are made and opportunities occur.

\section{Discussion}

Looking at the various metrics used to measure WP this integrated programme meets very few of them. Diversity is very poor with the entire population being almost exclusively white and male, however, this is in line with the sector as reported in Highton et al. At $8.85 \%$, the percentage of students on the programme from POLAR 3 quintile 1 postcodes is less than WUs total of $10 \%$ and substantially lower than the $22 \%$ reported by Smith et al for apprentices progressing to HE. Additionally, $32 \%$ of parents/guardians of the respondents have a degree (this is in line with an internal study conducted at WU in its engineering department which indicated 33-37\% of final year students had parents/guardians with degree) and $61 \%$ have class 1 or 2 occupations, leaving $25 \%$ with class $4-8$ occupations, again, broadly in line with WUs reported total. Additionally 50\% had commenced the programme after post GCSE level study suggesting some level of academic ambition. Of 26 schools named only 5 appear on the sample contextual admissions data consulted as being eligible for lower offers.

Thus a picture emerges of white upper middle class families considering career opportunities for their sons who may well see that an apprenticeship with sponsored educational opportunities to MEng level may well be a better option than full time study at university for a young male who is not keen on academic study. This notion matches the findings of the larger scale study by Higton, Emmett \& Halliday (2013:9) who report that the main motivations for doing an apprenticeship in this discipline area are gaining a qualification and progression. This apparent strategic type thinking underpinning career decisions is at odds with the findings of Archer et al (2001) who talk of haphazard path through education for working class males.

There is some indication that this programme does widen participation for mature students with $24 \%$ being over the age of 26 and $11 \%$ over the age of 30. This is much higher than the figures provided by Smith, Joslin \& Jameson who report figures of between 7\% and 5.7\% of over 25s on apprenticeships entered HE between 2006 and 2012 (note this is for all apprenticeships and is not sector specific) albeit they do note that the number of over $25 \mathrm{~s}$ on advanced apprenticeships has increased from $0.3 \%$ in 2006 to $40 \%$ in 2012. There are also 6 respondents who specifically state that they have served in the armed forces prior to joining the programme.

It should be noted at this point that of just under 300 engineering apprentices studying at the FE College $49 \%$ are 
studying level 2 qualifications. Additionally, the 23 apprentices taking the BTEC level 3 Subsidiary Diploma represent only $17 \%$ of the body of the level 3 engineering apprentices at the partner FE College. A further 76 are studying for City \& Guilds level 3 Craft qualifications and a further 34 for level 3 BTEC Technician qualifications. The City \& Guilds level 3 Craft qualifications do not provide sufficient UCAS points for them to progress to the HNC; with the level 3 BTEC Technician qualifications requiring an additional year to study to provide sufficient UCAS points. For academic year 15/16 of approximately 70 level 3 second year engineering apprentices at the partner FE College approximately 50\% progressed to the $\mathrm{HNC}$ with the majority of the remaining numbers entering from A levels and other FE colleges. The figure of 50\% is well in excess of the highest progression figure quoted by Joslin \& Smith (2014) of 37\% for the sector nationally. It should also be noted that decisions about what level of apprenticeship study is undertaken are made by the companies' employing the apprentices and no input from the FE College is made in this decision.

The results of this study would indicate that this integrated programme run as a collaboration between an FE College and an HEI does not obviously widen participation by the various metrics applied. Only a small percentage are considered to be from low participation neighbourhoods and only a quarter come from low socio-economic backgrounds. The qualitative data suggests that many of these found academic study not to suit them and, therefore, the option of an apprenticeship, that is practical work, with the possibility to gain academic qualifications was an attractive option without which many would not be on a path to HE qualification. However, as noted above the progression from level 3 engineering apprenticeships to the HNC (the first level of HE study) is much higher than the figure of $31 \%$ for this sector nationally.

Additionally, it is important to note that the decision about which apprentices are offered the chance to enter this integrated programme is made not by an education institution but by employers. It is suggested from this study that employers are looking for apprentices to take on different levels of employment, ranging from craft skills through to eventual management roles. This is supported by Colahan \& Johnson (2014) who report that employers from 'traditional' frameworks (in which engineering clearly fits) tend to recruit to their specific requirements rather than providing apprenticeships as training opportunities for existing staff. It might be surmised from this study that employers make the decision on which apprentices are offered which study options based on their GCSE results, that WP opportunities maybe being limited by early education achievements and by industry not educational institutions. This confirms the findings of Archer et al (2001) and The National Strategy for Access and Student Success (2014:42) discussed in the literature review. So it would appear that despite this integrated programme providing the kind of alternative

admission/progression routes ... particularly when accompanied by pedagogical reforms and activities that build up socio-cultural capital and familiarity with HE.' (2014:40)

suggested in the strategy document it has little impact when the decisions about who is given the opportunity to engage in the programme are outside the control of educational institutions. This is perhaps something for the Institute of Apprenticeships and Technical Education formed in April 2016 to further investigate. It may also be that with the introduction of the Apprenticeship Levy from April 2017 there may be an opportunity to engage employers in a dialogue about exploring greater diversity in their recruitment processes.

A further study is planned to investigate the backgrounds of all the level 2 and 3 engineering apprentices at the FE College to determine if there are more WP students on those apprenticeships with qualifications that don't lead to HE study. A clear limitation of this study is that only one population is considered which necessarily sits within a specific socio-economic setting, however, a detailed understanding of some of the issues which need further investigation is an important outcome and once, further research has been undertaken it will be possible to undertake a similar study in other UK regions to understand if the findings represent a national picture.

\section{Acknowledgements}

Thanks are due to the apprentices who took the time to complete the questionnaires and to the management of the FE College for allowing the researchers access.

\section{References}

Archer, L., Pratt, S. \& Phillips, D. (2013). Working-class Men's Constructions of Masculinity and Negotiations of (Non) Participation in Higher Education, Gender and Education, 13(4), 431-449. https://doi.org/10.1080/09540250120081779

Bowes, L., Thomas, L., Peck, L. \& Nathwani, T. (2013). International Research on the Effectiveness of Widening Participation, Report to HEFCE and OFFA by CFE and Edge Hill University. Avaiable at 
http://www.hefce.ac.uk/media/hefce/content/pubs/indirreports/2013/WP,international,research/2013_WPeffectiv eness.pdf (Accessed on 5th July 2017)

Burke, P.J. (2013). The Right to Higher Education: Beyond Widening Participation, Routledge.

Burke, P.J. (2016). Access to and Widening Participation in Higher Education, Encyclopedia of International Higher Education Systems and Institutions, Springer Science- Business Media, Dordrecht. https://doi.org/10.1007/978-94-017-9553-1_47-1

Colahan, M. \& Johnson, J. (2014). Apprenticeships Evaluation: Employers, BIS Research Paper 204. Available at https://www.gov.uk/government/uploads/system/uploads/attachment_data/file/387595/bis-14-1207-Apprentices hips-Evaluation-Employers-December-2014.pdf (Accessed on $15^{\text {th }}$ November 2016)

Dearing, R. (1997) Great Britain, National Committee of Inquiry into Higher Education - Higher Education in the Learning Society, London, HMSO

Department for Business, Innovation \& Skills (BIS). (2015). Green Paper - Fulfilling our Potential - Teaching Excellence, Social Mobility and Student Choice. Available at https://www.gov.uk/government/uploads/system/uploads/attachment_data/file/474227/BIS-15-623-fulfilling-our -potential-teaching-excellence-social-mobility-and-student-choice.pdf (Accessed on $22^{\text {nd }}$ Feb 2016)

Department for Business, Innovation \& Skills (BIS). (2015). Government rolls out flagship degree apprenticeships. Available at https://www.gov.uk/government/news/government-rolls-out-flagship-degree-apprenticeships (Accessed 5th May 2017)

Department for Business \& Skills. (2015). Widening Participation in Higher Education. Available at https://www.gov.uk/government/uploads/system/uploads/attachment_data/file/443986/Widen-Partic-HE-2015s. pdf (Accessed on $18^{\text {th }} \mathrm{Feb} 2017$ )

Department for Education (DfE). (2017). Guidance: Apprenticeship Funding, How it will work. Available at https://www.gov.uk/government/publications/apprenticeship-levy-how-it-will-work/apprenticeship-levy-how-itwill-work (Accessed on 7th April 2017)

Department for Education and Employment (DfEE). (1998). Higher Education for the 21 ${ }^{\text {st }}$ Century: response to the Dearing Report.

Department for Education and Employment (DfEE). (1999). Learning to Succeed: a New Framework for Post-16 Learning, Sudbury, DfEE Department for Education and Skills (DfES) (2003) The Future of Higher Education, White Paper, London, HMSO

Fryer, R (1997). Learning for the Twenty-First Century: first report of the National Advisory Group for Continuing Education and Lifelong Learning, London.

Department for Education and Schools (DES), (1987) Meeting the Challenge, White Paper, London, HMSO Department for Education and Schools (DES), (1991) Higher Education: a new framework, White Paper, London,

\section{HMSO}

Gale, T and Parker, S. (2013). Widening Participation in Australian Higher Education, Report Submitted to HEFCE and OFFA, Edge Hill University and CFE Research. Available at http://dro.deakin.edu.au/eserv/DU:30064915/gale-wideningparticipation-2013.pdf (Accessed 5th July 2017)

Gorard, S. (2008). Who is missing from Higher Education? , Cambridge Journal of Education, 38(3), 421-437. Available at http://www.tandfonline.com/doi/full/10.1080/03057640802286863?scroll=top\&needAccess=true (Accessed 5thJuly 2017) https://doi.org/10.1080/03057640802286863

Higher Education Funding Council for England (HEFCE), (2015) POLAR - Participation of Local Areas. Available: http://www.hefce.ac.uk/analysis/yp/POLAR/ [Access on $22^{\text {nd }}$ February 2017]

HEFCE. (2017). POLAR Map of Young Participation Areas. Available: http://www.hefce.ac.uk/analysis/yp/POLAR/Map,of,young,participation,areas/ [Accessed on $27^{\text {th }}$ February 2017]

HEFCE, Post code checker. Accessed on $15^{\text {th }}$ November 2016 at http://www.hefce.ac.uk/postcode/

HEFCE and OFFAa. (2013). National Strategy for access and student success: Interim report to the Department for Business, 
https://www.offa.org.uk/wp-content/uploads/2013/03/National-strategy-interim-report-January-2013.pdf (Accessed on $22^{\text {nd }}$ Feb 2016)

HEFCE and OFFAb. (2014). National Strategy for Access and Student Success. Available at https://www.gov.uk/government/uploads/system/uploads/attachment_data/file/299689/bis-14-516-national-strat egy-for-access-and-student-success.pdf (Accessed on $22^{\text {nd }}$ Feb 2016)

Higher Education Statistics Agency (HESA) - UKPEI Definitions. Available at https://www.hesa.ac.uk/pis/defs (Accessed on $18^{\text {th }}$ Feb 2016)

Higton, Emmett, \& Halliday. (2013). Apprenticeship Evaluation: Learners, BIS Research Paper 124.

Her Majesty's Revenue and Customs (HMRC) (2016) Policy Paper Apprenticeship Levy. Available at https://www.gov.uk/government/publications/apprenticeship-levy/apprenticeship-levy (Accessed on 5th April 2017)

Joslin, H and Smith, S. (2013). Progression of Apprentices to Higher Education in London - 2004-2010, BIS Research Paper $107 . \quad$ Available at http://www.linkinglondon.ac.uk/downloads/data-resources/PROGRESSION\%20OF\%20APPRENTICES\%20T O\%20HIGHER\%20EDUCATION\%20IN\%20LONDON\%2019-09-2013.pdf (Accessed on $15^{\text {th }}$ November 2016)

Joslin, H and Smith, S. (2014). Progression of Apprentices to Higher Education - cohort update, BIS Research Paper 176. Available

http://dera.ioe.ac.uk/20121/1/bis-14-795-progression-of-apprentices-to-highe-education-cohort-update.pdf (Accessed on $15^{\text {th }}$ November 2016)

Mirza-Davies, J. (2016). Apprenticeship Statistics - Briefing Paper number 06113. House of Commons Library. Available at researchbriefings.files.parliament.uk/documents/SN06113/SN06113.pdf (Accessed on 17 $7^{\text {th }}$ April 2017)

National Committee on Education. (1993). Learning to Succeed. A Radical look at Education Today and a Strategy for the Future, Report of the Paul Hamlyn Foundation, Heinemann, London.

National Committee of Inquiry into Higher Education [NCIHE]. (1997). Higher Education in the Learning Society, London, Stationary Office

National Audit Office, (2002). Widening participation in higher education in England, London, HMSO Osborne, M. (2003) Increasing or Widening Participation in Higher Education? - a European overview, European Journal of Education, 38(1), 5-24. https://doi.org/10.1111/1467-3435.00125

Secretary of State for Business, innovation and Skills. (2016). Letter of Guidance from the Secretary of State for Business, Innovation and Skills and the Minister of State for Universities and Science to the Director of Fair Access. Available at https://www.offa.org.uk/wp-content/uploads/2016/02/11-02-2016-OFFA-Guidance.pdf (Accessed on $15^{\text {th }}$ November 2016)

Office for National Statistics, National Statistics Socio-economic classification (NS SEC rebased on SOC2010). Available http://webarchive.nationalarchives.gov.uk/20160105160709/http://www.ons.gov.uk/ons/guide-method/classifica tions/current-standard-classifications/soc2010/soc2010-volume-3-ns-sec--rebased-on-soc2010--user-manual/ind ex.html (Accessed on 15th November 2016)

Smith, S., Joslin, H and Jameson, J. (2015). Progression of Apprentices to Higher Education $-2^{\text {nd }}$ cohort update, BIS Research Paper $240 . \quad$ Available at https://www.gov.uk/government/uploads/system/uploads/attachment_data/file/460455/BIS-15-530-progressionof-apprentices-to-higher-education.pdf (Accessed on 15th November 2016)

Times Higher Education Supplement. (2003) 10 ${ }^{\text {th }}$ January: 18.

\section{Notes}

Note 1. Educational levels are specified by the UK Government and details can be found at https://www.gov.uk/what-different-qualification-levels-mean/list-of-qualification-levels

Note 2. https://www.gov.uk/government/organisations/institute-for-apprenticeships 